\title{
Pemanfaatan E-Commerce Dalam Upaya Meningkatkan Volume Penjualan Pada Mitra Keripik Pisang Arjuna Di Yosodadi Metro Timur
}

\author{
Ira Vahlia ${ }^{1}$, Nina Lelawati ${ }^{2}$ \\ Universitas Muhammadiyah MetroLampung \\ 1'iravahlia768@yahoo.co.id \\ 2 neesky_takky@yahoo.co.id
}

\begin{abstract}
Small industry is a profitable business opportunity. The home industry partner of the banana arjuna chips is the banana chips of the home industry, the pride of Yosodadi Metro Timur Village, Lampung. The crispy chips made available are excellent for the Javanese provinces. But in its production every home industry has a variety of problems that make it impossible for home industries to grow and even go bankrupt because they are unable to keep up with the development of the world of commerce that follows developments that rely heavily on technology. Partners still use product sales manually, ie consumers come directly to partners to buy banana chips. To facilitate partners in the sale of banana chips, assistance is provided in partner communities in managing online marketing management and training in making e-commerce systems online, and conducting online system simulations to support the sales process optimally. To ensure the success of the program, an evaluation will be carried out at each stage of program development. So that the sustainability of the business unit will continue as an activity that can improve the economy of the community in the partner environment and can absorb local labor.
\end{abstract}

Keywords: Banana Crackers, E-Commerce.

\section{PENDAHULUAN}

Home industri yang ada di kotakota kecil banyak yang mengalami gulung tikar dikarenakan tidak dapatnya mengikuti perkembang dunia yang semakin cangih, khususnya dalam bidang Information and Communication Technolongies (ICT). Menurut Sirajuddin (2017) Home industri adalah tulang punggung perekonomian bangsa yang mampu bertahan di saat krisis, yang menyentuh kehidupan masyarakat miskin. Industri merupakan kegiatan ekonomi dimana dalam kegiatanya menggolah bahan mentah menjadi bahan setengah jadi, atau pun bahan setengah jadi menjadi bahan jadi yang bisa langsung dikonsumsi oleh konsumen. Mitra dalam program ini yaitu Home industri keripik pisang arjuna, mitra sudah berjalan dalam dari tahun 2015 hingga sekarang. Keripik pisang Arjuna termasuk makanan ringan yang murah dan mudah didapat. Meskipun demikian, pemasaran yang diperoleh Home industri keripik pisang arjuna yang memiliki beberapa macam rasa ini tidak membuat pendapatan Home industri itu tinggi. Hal ini dikarenakan promosi pemasaran belum mengunakan $E$ Commerce dalam pemasarannya kepada khalayak. Sehingga hasil produksi yang dihasilkan hanya diketahui sekitar kawasan tersebut.

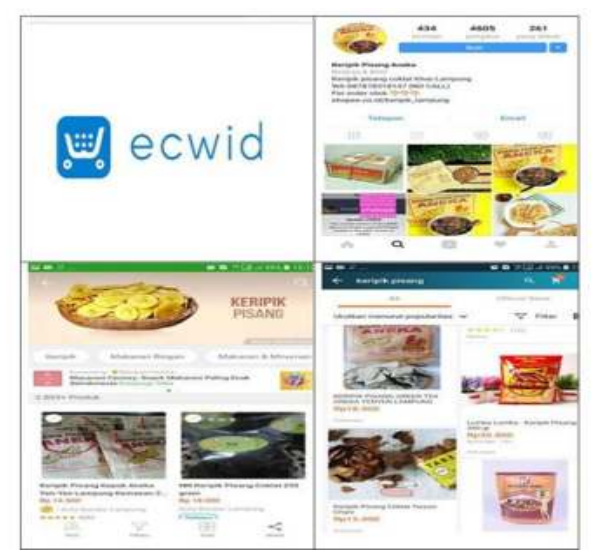

Gambar 1 Contoh produk yang dijual $E$ Commecre di Ecwid Tokopedia, Bukalapak, dan Instagram. 
Mitra hanya menjual hasil produknya dengan memanfaatkan etalase dengan ukuran ruangan $3 \times 4 \mathrm{~m}^{2}$ didepan rumahnya. Proses promosi yang masih konvensional menjadikan masalah bagi calon konsumen yang akan membeli produk dari arjuna, sehingga jika calon konsumen tidak dapat menemukan letak Arjuna, maka akan mengurungkan niatnya untuk membeli produk dari Arjuna tersebut. Secara tidak langsung hal ini menjadi kerugian bagi Arjuna. Pelanggan harus datang ke tempat penjual untuk mengetahui ada tidaknya produk baru. Tentu cara seperti ini menjadi kurang efisien karena dibutuhkan waktu yang lama dan tambahan biaya untuk seorang calon konsumen mengetahui informasi suatu produk. Menurut Nasrullah (2017) dengan memanfaatkan E-Commerce berbasis IT memberikan perubahan lebih cepat terhadap masayarakat dalam konteks ekonomi dan pendidikan. Dengan $e$ commerce, mitra dapat melakukan transaksi bisnis dengan lancar dan memperluas jaringan dalam bertransaksi online.

Perkembangan bisnis secara online yang ada di Indonesia sekarang sangat pesat, hal ini didukung dengan adanya belanja secara online. Belanja online merupakan salah satu cara yang dapat diambil dengan memanfaatkan alat komunikasi elektronik atau jejaring sosial, dimana seorang dalam transaksi pembeli tidak perlu selalu datang ke suatu toko ataupun perusahaan untuk membeli suatu barang yang diinginkan. Diera digitalisasi saat ini e-commerce merupakan salah satu alternatif pilihan untuk sebuah perusahaan yang khususnya bergerak di bawah wiraswasta sebagai media informasi yang memudahkan adanya interaksi antara penjual dan pembeli tanpa dibatasi ruang dan waktu. Dengan didukung oleh perkembangan teknologi informasi yang semakin canggih dan mudah didapat, perkembangan e-commerce semakin bertambah dan semakin diminati banyak perusahaan ataupun home industri.
Berdasarkan latar belakang masalah yang dihadapi mitra, adapun yang menjadi tujuan dari pengabdian adalah sebagai berikut: (1) Membekali mitra dengan memberikan mitra pelatihan ICT oleh para ahli, pelatihan diberikan dengan harapan mitra dapat mengoprasikan ICT pada alat komunikasi yang dilengkapi dengan aplikasi online. (2) Pendampingan, diberikan kepada mitra dengan tujuan untuk mitra dapat mendesain brand agar memberikan penguatan kepada produk yang dihasilkan.

Manfaat penggunaan sistem penjualan online ini dapat menguntungkan banyak pihak, baik pihak konsumen, produsen maupun penjual. Konsep online shop menyediakan banyak kemudahan dan kelebihan jika dibandingkan dengan konsep belanja yang konvensional. Selain proses transaksi bisa menjadi lebih cepat, konsep toko online atau e-commerce dapat memangkas banyak biaya operasional karena penjual tidak diharuskan punya toko fisik. Sistem Informasi adalah kombinasi antara prosedur kerja, informasi, orang dan teknologi informasi yang diorganisasikan untuk mencapai tujuan dalam sebuah organisasi internet adalah seluruh jaringan yang saling terhubung satu sama lain. Beberapa komputer dalam jaringan ini menyimpan file, seperti halaman web, yang dapat diakses oleh seluruh jaringan komputer maupun handphone dan tablet. Melihat pangsa pasar, peluang serta kemudahan yang dihadirkan oleh sistem penjualan online, penulis berencana membuat sistem dan menjajaki pasar online yang sekarang makin digemari oleh masyarakat terutama kalangan menengah keatas.

Penjualan yang dilakukan dengan memanfaatkan ICT diharapkan nantinya akan membuka kesempatlebih luas untuk konsumen dapat mengenal produk tanpa harus berkunjung ditempat produksi. Adapaun mafaat dari hasil pengabidan ialah sebagai berikut: 
a) Mitra memiliki akun pada pada aplikasi jual beli online

b) Mitra memperoleh pengetahuan baru terkait dengan ICT

c) Mitra memiliki pengetahuan dan kemampuan untuk melakukan pembukuan dengan baik.

\section{KAJIAN TEORI}

\section{A. Pemasaran}

Pemasaran dalam suatu perusahaan memiliki peranan yang sangat penting, hal ini dikarenakan pemasaran adalah kegiatan yang dilakukan untuk tetap mempertahankan kelangsungan hidup dan untuk mencapai tujuan untuk memperoleh keuntungan yang ditargetkan sutau pemasaran. Pengertian pemasaran memiliki penekanan dalam penyajian yang berbeda-beda, namun sebenarnya mempunyai pengertian yang satu samala lain tidak jauh berbeda. Menurut Daryanto (2011:1) pemasaran merupakan suatu proses sosial dan manajerial dimana individu dan kelompok mendapatkan kebutuhan dan keinginan mereka dengan menciptakan, menawaran dan bertukar sesuatu yang bernilai satu sama lain". Sedangkan menurut Swastha (2009:5) mendifinikan: Pemasaran adalah keinginan manusia yang diarahkan pada usaha untuk memuaskan keinginan dan kebutuhan melalui proses pertukaran". Menurut Nembah (2011:10) unsur bauran pemasaran untuk mencapai tujuan pemasaran, maka keempat variabel tersebut harus saling mendukung satu sama lain atau dengan kata lain, manajemen harus berusaha agar variabel-variabel bauran pemasaran atau Marketing Mix dapat terpandu untuk mencapai tujuan yang telah ditetapkan. Adapun keempat variabel bauran pemasaran atau Marketing Mix tersebut: Produk, Harga, Promosi, dan Tempat (Saluran Distribusi), atau sering disebut 4P (Produce, Price, Promotion, Place).
1) Produk (Product): kombinasi "barang dan jasa" yang ditawarkan kepada pasar.

2) Harga (Price): sejumlah uang yang harus dibayarkan oleh konsumen untuk mendapatkan produk.

3) Promosi (Promotion): Semua kegiatan perusahaan untuk memperkenalkan atau meningkatkan mutu produk dan bertujun agar konsumen tertarik untuk membelinya.

4) Tempat (Place): Saluran yang digunakan oleh produsen untuk menyalurkan produk tersebut dari produsen sampai ke konsumen atau industri pemakai dan Saluran distribusi merupakan struktur unit oranisasi dalam perusahaan dan luar perusahaan yang berdiri dari agen, perdagangan besar, dan pengecer melalui mana suatu produk atau jasa dipasarkan.

Berdasarkan beberapa teori pemasaran di atas dapat disimpulkan bahwasanya pemasaran meliputi usaha dari seseorang ataupun perusahaan yang dimulai dengan mencari apa yang dibutuhkan konsumen agar merasa terpuaskan oleh langkah yang diambil. Pemasaran akan menentukan jenis barang atau saja yang akan dijual belikan kepada khalayak ramai melalui strategi pemasaran yang telah dipilih, karena hal ini juga akan mempengaruhi penentuan harga barang dan jasa yang akan ditawarkan kepada konsumen. Komponen e-commerce dapat dilihat pada bagan berikut ini:

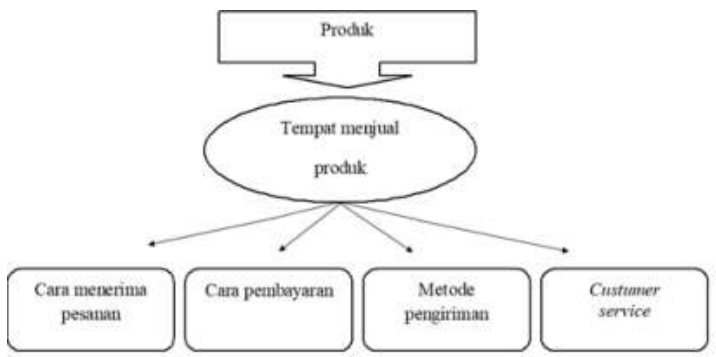

Gambar 2 Komponen E-Commerce

Menurut Maulana (2015) ada beberapa kelebihan yang dimiliki $e$ commerce dan tidak dimiliki oleh transaksi bisnis yang dilakukan secara offline, 
beberapa hal tersebut adalah sebagai berikut ini :

1) Produk: Banyak jenis produk yang bisa dipasarkan dan dijual melalui internet seperti pakain, mobil, sepeda dll.

2) Tempat menjual produk: tempat menjual adalah internet yang berarti harus memiliki domain dan hosting.

3) Cara menerima pesanan: Email, telpon, sms dan lain-lain.

4) Cara pembayaran: Credit card, Paypal, Tunai, transfer rekening.

5) Metode pengiriman: Menggunakan Pos Indonesia, EMS, atau JNE

6) Customer service: email, Contact us, Telepon, Chat jika tersedia dalam software.

Dari gambar tersebut, home industri keripik pisang arjuna sudah memiliki produk namun belum memiliki domain dan hosting. Belum memiliki kemampuan dalam menerima pesanan, cara pembayaran melalui transfer rekening. Serta memiliki kontak custumer service. Dengan penjualan belum menggunakan E-Commerce tersebut menjadi penghambat calon konsumen baru dan bagi mitra untuk memaksimalkan pendapatannya. Suparjo (2017) menyatakan bahwa home industri yang mandiri dan lebih dikenal masyarakat secara luas dapat tercapai sehingga tujuan akhir program meningkatkan taraf hidup menjadi lebih sejahtera dapat terwujud. Promosi yang dilakukan kelompok mitra

\section{B. Volume Penjualan}

Besar kecilnya modal kerja sangat dipengaruhi oleh volume penjualan. Suatu perusahaan menanamkan sebagaian dananya dalam bentuk modal kerja, oleh sebab itu hasil penjualan diperlukan kegiatan oprasional yang bertumpu pada kegiatan penjualan. Menurut Basu Swasta (2005:65) berpendapat bahwa volume penjualan merupakan penjualan bersih dari laporan laba perusahaan. Penjualan bersih diperoleh melalui hasil penjualan seluruh produk (produk lini) selama jangka waktu tertentu dan hasil penjualan yang dicapai dari market share (pangsa pasar) yang merupakan penjualan potensial yang dapat terdiri dari kelompok pembeli selama jangka waktu tertentu.

Menurut Efendi Pakpahan (2009) faktor yang sangat penting dalam mempengaruhi volume penjualan adalah saluran distribusi yang bertujuan untuk melihat peluang pasar apakah dapat memberikan laba yang maksimun. Secara umum mata rantai saluran distribusi yang semakin luas akan menimbulkan biaya yang lebih besar, tetapi semakin luasnya saluran distribusi maka produk perusahaan akan semakin dikenal oleh masyarakat luas dan mendorong naiknya angka penjualan yang akhirnya berdampak pada peningkatan volume penjualan.

Volume penjualan adalah penjualan yang berhasil dicapai aatau ingin dicapaioleh suatu perusahaanmemalui jumlah produk atau merek suatu perusahaan yang terjual dalam suatu jangka waktu tertentu (Kamelia, 2006:38). Diperkuat oleh pendapat Rangkuti (2009:207), volume penjualan adalah pencapaian yang dinyatakan secara kuantitatif dari segi fisik atau volume atau unit suatu produk. Volume penjualan merupakan suatu yang menandakan naik turunnya penjualan dan dapat dinyatakan dalam bentuk unit, kilo, ton atau liter. Sedangkan menurut Kotler dalam Swasta dan Irwan (2012:23), indikator dari volume penjualan adalah mencapai volume penjualan tertentu, mendapat laba tertentu dan menunjang pertumbuhan perusahaan

Berdasarkan penjelasan diatas dapat disimpulkan bahwa ada beberapa faktor yang dapat mempengaruhi volume penjualan, faktor-faktor tersebut ada yang bisa ditanggulangi oleh perusahaan ada juga yang sukar untuk ditanggulanginya. Perusahaanpun harus jeli melihat keadaan atau kondisi pasar, keinginan konsumen dan perekonomian negara. 


\section{METODE PENGABDIAN}

Metode yang ditawarkan untuk menyelesaikan masalah yang dihadapi mitra dalam pemasaran E-commerce dilakukan dengan langkah-langkah sebagai berikut:

\section{A. Melakukan Program Pelatihan}

1) Pelatihan menggunakan aplikasi Ecommerce dalam pemasaran: Pelatihan ini ditujukan untuk mitra memiliki akun dan mengoprasikan E-commerce dalam aplikasi Ecwid, Tokopedia, Bukalapak, Lazada dan Instagram.

2) Pelatihan join grup E-commerce: dengan memperluas jaringan dalam relasi pemasaran produk secara online ini sangat dibutuhkan, karena semakin banyak relasi tentunya akan memberikan pengaruh positif pada mitra. Mitra dapat berkerja sama dengan toko onlineshop yang ada pada aplikasi untuk dapat memasarkan produknya.

\section{B. Pemberian Pendampingan}

Pendampingan dilakukan secara kontinue selama pengabdian berlangsung yaitu dengan cara terus memantau perkembangan penjualan produk keripik pisang dalam aplikasi e-commerce.

\section{Teknik Kerja PKM Keripik Pisang}

Secara prosedur untuk melaksanakan PKM kripik pisang dapat diuraikan sebagai berikut:

1) Tahap Pra-Survei untuk menemukan masalah dan mitra yaitu melihat secara langsung bagaimana penjualan produk keripik pisang Arjuna.

2) Memilih jenis pelatihan dan pendampingan serta narasumber yang kompeten dibidang permasalahan yang telah ditentukan. Narasumber berasal dari dosen Universitas Muhammadiyah Metro yaitu pengabdi sendiri Ibu Ira Vahlia, M. Pd. dan Ibu Nina Lelawati, MM. Yang telah berpengalaman dalam mengelola akun aplikasi $e$-commerce.

3) Menyiapkan bahan-bahan pelatihan dan pendampingan seperti materi, laptop, wifi maupun handphone (HP) android yang dipakai pada saat pelatihan.

4) Melakukan Field trip kepada home industri yang telah memasarkan produknya dengan menggunakan pemasaran E-commerce.

\section{Alur Kegiatan PKM Kripik Pisang}

Alur kegiatan kripik pisang yang pelaksanaanya selama 8 bulan dengan tahapan sebagai berikut:

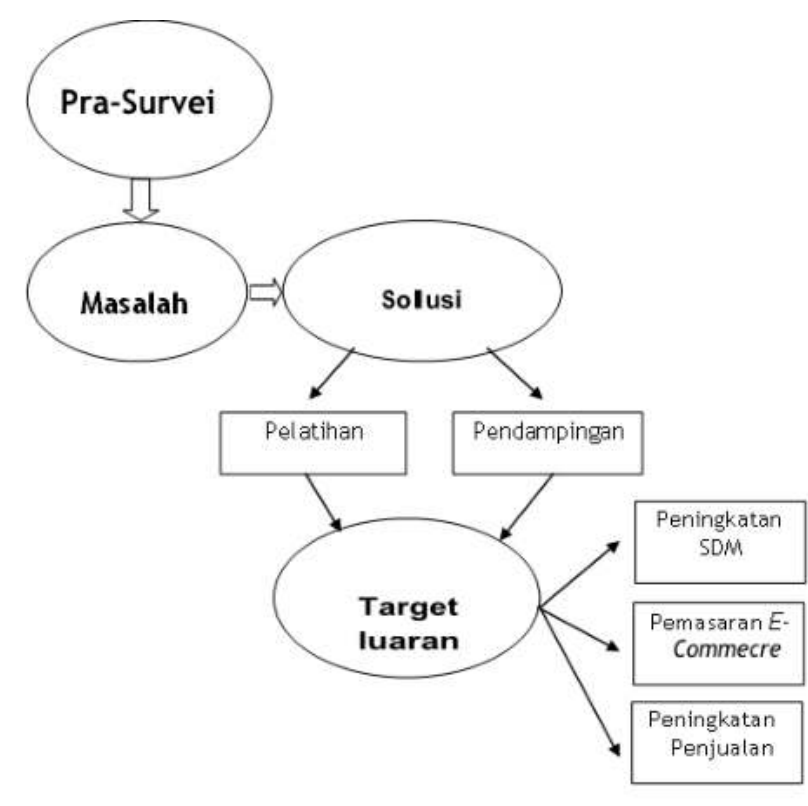

Gambar 3. Alur Kegiatan PKM Keripik Pisang

Dari Gambar 3 diatas, pengabdi melakukan prasurvei kepada mitra yaitu home industri keripik pisang arjuna di Yosodadi Metro Timur yaitu penjualan produk masih secara langsung belum secara online. Masalah lainnya yaitu mitra belum pernah mendapatkan pelatihan $e$ commerce yang dapat memperluas jaringan penjualan baik didalam kota maupun luar kota. Pengabdi memberikan solusi bahwa diperlukan pelatihan dan pendampingan $e$ commerce kepada mitra karena pada saat ini, teknologi sangat mumpuni dalam mengembangkan usaha atau industri kecil. 


\begin{tabular}{|c|c|c|c|}
\hline \multicolumn{4}{|c|}{$\begin{array}{c}\text { TABEL II } \\
\text { MATERI PELATIHAN PENINGKATAN } \\
\text { VOLUME PENJUALAN DENGAN E- } \\
\text { COMMERCE }\end{array}$} \\
\hline No & $\begin{array}{c}\text { Materi } \\
\text { Pengabdian }\end{array}$ & Jml & Tujuan \\
\hline 1 & $\begin{array}{l}\text { Jenis-Jenis } E \text { - } \\
\text { Commerce }\end{array}$ & 3 jam & $\begin{array}{l}\text { Peserta program } \\
\text { mengetahui jenis- } \\
\text { jenis onlineshop } \\
\text { yang dapat dipakai } \\
\text { dalam } \\
\text { mempromosikan } \\
\text { produk. }\end{array}$ \\
\hline 2 & $\begin{array}{l}\text { Pola pemasaran } \\
\text { E- commerce }\end{array}$ & 3 jam & $\begin{array}{l}\text { Peserta program } \\
\text { mempunyai } \\
\text { kemampuan dalam } \\
\text { Marketing Online. }\end{array}$ \\
\hline 3 & $\begin{array}{l}\text { Ketrampilan } \\
\text { Interaksi } \\
\text { dengan } \\
\text { Konsumen di } \\
\text { pemasaran } E \text { - } \\
\text { Commerce }\end{array}$ & 3 jam & $\begin{array}{l}\text { Perserta } \\
\text { program } \\
\text { mempunyai } \\
\text { kemampuan dalam } \\
\text { berinteraksi } \\
\text { dengan konsumen } \\
\text { yang membeli } \\
\text { barang di toko } \\
\text { onlineshop yang } \\
\text { telah mereka buat. }\end{array}$ \\
\hline 4 & $\begin{array}{l}\text { Ketrampilan } \\
\text { Gabungan } \\
\text { dan } \\
\text { Kerjasama }\end{array}$ & 3 jam & $\begin{array}{l}\text { Perserta } \\
\text { program } \\
\text { mempunyai } \\
\text { kemampuan } \\
\text { bekerjasama } \\
\text { dengan sesama } \\
\text { toko E-Commerce } \\
\text { lain, serta } \\
\text { berinteraksi } \\
\text { dengan pemilik } \\
\text { toko untuk } \\
\text { meningkatkan } \\
\text { pemasaran produk } \\
\text { keripik pisang. }\end{array}$ \\
\hline
\end{tabular}

\section{PEMBAHASAN}

Program kemitraan masyarakat (PKM) dimana mitra pengabdian adalam keripik pisang Arjuna. Untuk meningkatkan kualitas sumberdaya manusia dalam bidang ICT dilakukan dengan memberikan pelaitihan ICT dan $E$ commerce. Hasil dari pelatihan tersebut dapat diketahui bahwa kemampuan ICT dan pemasaran melalui e-commerce meningkat, hal ini terlihat dari hasil pelatihan mitra mampu mengunakan mengoprasikan alat komunikasi yang didalamnya terdapat aplikasi online dan mitra juga mampu memasarkan produk yang dihasilkan pada aplikasi online seperti Lazzada, Shopee dan bukalapak. Berdasarkan pelatihan dan pendampingan pada mitra dapat dilihat pada gambar berikut ini:

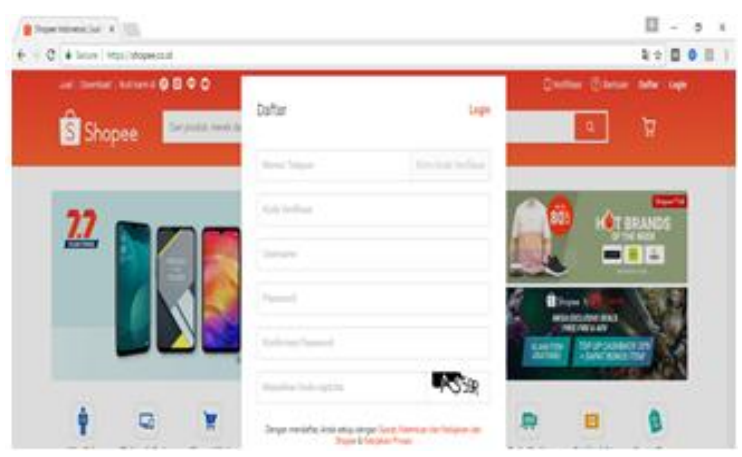

Gambar 4. Tampilan Login pada Aplikasi Ecommerce

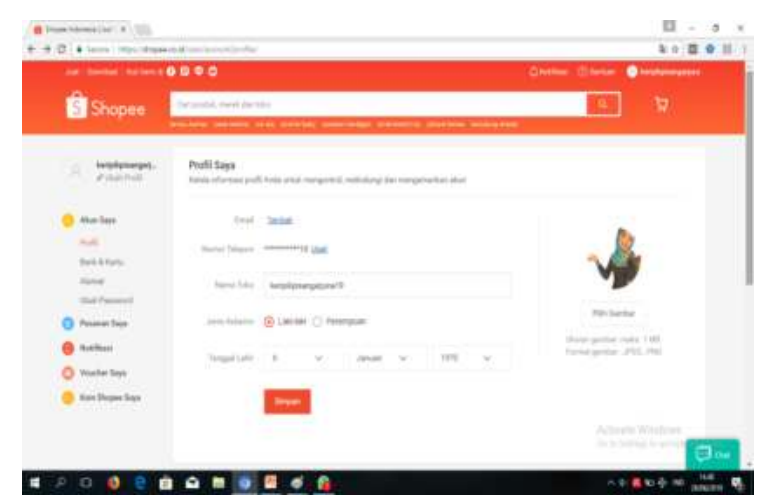

Gambar 5. Tampilan Pembuatan Akun pada Aplikasi E-commerce

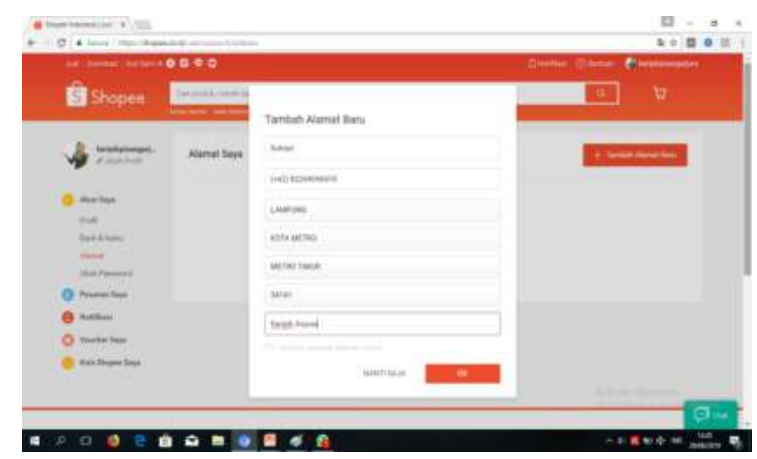

Gambar 6. Alamat Mitra Dimasukkan Kedalam Aplikasi 


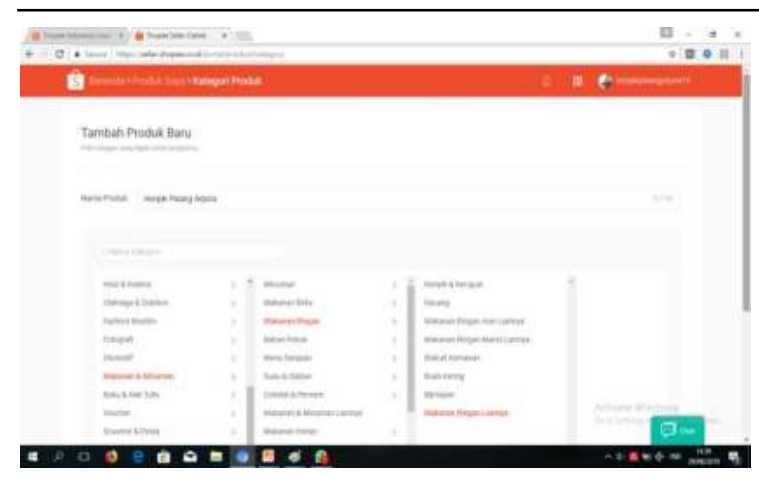

Gambar 7. Input Data Produk Keripik Pisang Arjuna

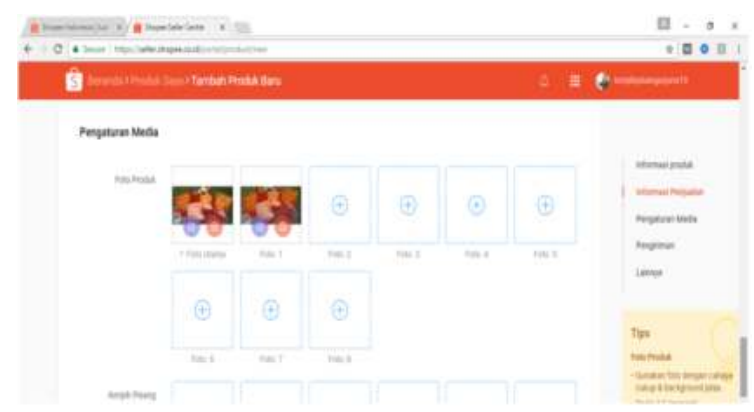

Gambar 8. Input Foto Produk Keripik Pisang Arjuna

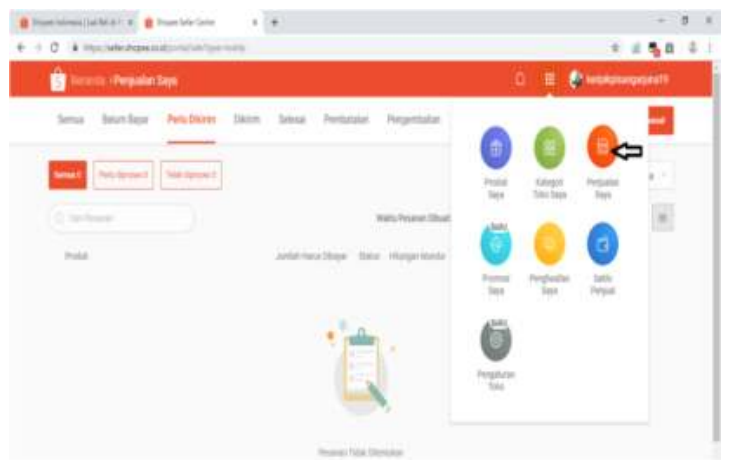

Gambar 9. Tampilan Penjualan Mitra pada Aplikasi E-commerce

Pengabdi melakukan pendampingan secara langsung kepada mitra sampai dengan memiliki akun pada aplikasi $e$ commerce. Aplikasi ini dapat memuat informasi yang dibutuhkan oleh konsumen terkait keterangan produk keipik pisang Arjuna seperti berat produk, bentuk, rasa yang bervariasi, bahan yang digunakan untuk membuat keripik, video langsung produk maupun jasa pengiriman yang dipilih konsumen untuk mengirimkan keripik ke alamatnya. Aplikasi ini sangat memudahkan konsumen sehingga produk dapat sampai ketangan konsumen dengan cepat dan utuh tidak perlu langsung datang ke toko keripiknya. Bahkan informasi tentang produk terbaru keripik pisang Arjuna dapat dipublikasikan kepada konsumen dengan baik.

\section{KESIMPULAN DAN SARAN}

Kegiatan pengabdian yang telah dilakukan dengan pelatihan dan pendampingan secara umum telah memenuhi target yang telah ditetapkan pengabdi. Mengacu pada analisis dan kegiatan yang telah dilakukan maka melalui program kemitraan masyarakat ini dapat disimpulkan bahwa:

a) Guna meningkatakn volume penjualan keripik pisang dapan mengunakan penjualan online ataupun mengunakan aplikasi berbasis online agar produk yang dipasarkan dapat diketahui oleh khalayak ramai dengan jangkau luas.

b) E-commerce dapat dijadikan sebagai solusi dalam memasarakan produk dari produsen kepada konsumen karena dengan pemasaran melalui e-commerce dapat meningkatkan volume penjualan keripik pisang arjuna.

c) Dengan dilakukannya penjualan secara online diharapkan penjual dapat memberikan kemudahan dan kenyamanan dalam melakukan transaksi jual beli online.

Berdasarkan pelaksanaan kegiatan program kemitraan masyarakat, pegabdi merasa masih menemui kendala yang perlu disempurnakan, sehingga perlu diberikan saran baik kepada mitra maupun pengusaha yang sebidang. Adapun saran yang dapat pengabid berikan addalah sebagai berikut:

a) Guna meningkatkan volume penjualan keripik pisang dapat mengunakan penjualan online ataupun mengunakan aplikasi berbasis online agar produk yang dipasarkan dapat diketahui oleh khalayak ramai dengan jangkau luas. 
b) E-commerce dapat dijadikan sebagai solusi dalam memasarakan produk dari produsen kepada konsumen karena dengan pemasaran melalui e-commerce dapat meningkatkan volume penjualan keripik pisang Arjuna.

c) Dengan dilakukannya penjualan secara online diharapkan penjual dapat memberikan kemudahan dan kenyamanan dalam melakukan transaksi jual beli online.

\section{DAFTAR PUSTAKA}

1. Assauri, Sofjan. 2004. Manajemen Pemasaran. Jakarta: Rajawali Press.

2. Basu, Swastha. 2001. Manajemen Penjualan, cetakan kelima. BFSE : Yogyakarta.

3. Basu Swastha.(2009). Manajemen Penjualan. Yogyakarta: BPFE

4. Basu Swastha, Dharmesta dan Irawan, 2012, Manajemen Pemasaran Modern, Liberty, Yogyakarta.

5. Daryanto. 2011. Manajemen Pemasaran: Sari Kuliah. Bandung: Satu Nusa.

6. Hartimbul Ginting, Nembah F. 2011. Manajemen Pemasaran. Bandung: CV Yrama Widya

7. Hendrayanti, nadimin, sirajuddin, hasanak, Su. 2014. Hubungan pola asuh dan asupan zat gizi pada baduta stunting dan atau wasting di kelurahan allepolea kecamatan Lau kabupaten maros. Media gizi pangan.

8. Kartajaya, hermawan. 2004. Hermawan kartajaya on brand. Bandung: mizan pustaka

9. Kamelia, Lisia. 2006. Pengaruh Harga Jual dan Biaya Promosi Terhadap Volume Penjualan Teh pada SBUTK PT Perkebunan Nusantara VI (Persero) Jambi - Sumatera Barat. Skripsi. Program Studi Bisnis dan Manajemen Fakultas Bisnis dan Manajemen Universitas Widyatama. Bandung [online]
10. Rangkuti, Freddy. ((2009). Strategi Promosi yang Kreatif dan Analisis Kasus Integrated Marketing Communication. Jakarta : PT. GramediaPustakaUtama

11. Suparjo. 2008. Saponin, peran dan pengaruhnya bagi ternak dan manusia. Laboratorium Makanan Ternak. Fakultas Peternakan. Universitas Jambi. http//:jojo66.wordpress.com.

[29 Desember 2016]. 